\title{
EFFECT OF E-FILING SYSTEM IMPLEMENTATION AND TAX KNOWLEDGE ON TAXPAYER COMPLIANCE WITH ACCOUNT REPRESENTATIVE SERVICES AS MEDIATION VARIABLE (Case Study on Personal Taxpayers at KPP Pratama, East Tangerang)
}

\author{
Hasian Purba \\ Accounting Study Program, Faculty of Economics and Business, Universitas Mercu Buana, \\ Jakarta, Indonesia
}

Article DOI: https://doi.org/10.36713/epra4508

\begin{abstract}
The purpose of this study is as follows: 1) Finding empirical evidence regarding the effect of the application of efiling systems to account representative services; 2) Finding empirical evidence regarding the effect of tax knowledge on account representative services; 3 ) Finding empirical evidence regarding the effect of applying the efiling system to taxpayer compliance; 4) Finding empirical evidence regarding the influence of tax knowledge on taxpayer compliance; and 5) Finding empirical evidence regarding the effect of account representative services on taxpayer compliance. This type of research used in this study is causal which will test the hypothesis about the effect of one or several independent variables on the dependent variable. The population in this study were all Individual Taxpayers registered at East Tangerang KPP. Sample selection with purposive sampling method. The analytical method used to test hypotheses is the path analysis test and multiple test. The results showed that: 1) The application of e-Filing system had a direct effect on the Account Representative service; 2) Knowledge of taxation directly affects the service of Account Representatives; 3) The application of the e-Filing system has a direct effect on the compliance of taxpayers; 4) Tax knowledge directly affects the compliance of taxpayers; and 5) Account Representative services directly affect the compliance of taxpayers.
\end{abstract}

KEYWORDS: Application of E-Filing System, Account Representative Services, Taxpayer Compliance

\section{INTRODUCTION}

Taxes are obtained from community contributions (taxpayers) using the self assessment system. The self assessment system is a system of reform carried out by the Directorate General of Taxes. This system replaces the previous official assessment system. The self assessment system is a system where the Taxpayer is given the trust to calculate and self-report the tax owed by the Taxpayer, while the tax officer himself has the duty to monitor it. That means the success or failure of this system is largely determined by the voluntary compliance of the taxpayers and optimal supervision of the tax authorities themselves. This system is very dependent on the awareness of taxpayers in fulfilling their tax obligations there are still many taxpayers who are not compliant to report and pay taxes.
The Directorate General of Taxes seeks to increase tax revenue revenue by making changes to tax regulations. The Directorate General of Tax also tries to provide excellent service to taxpayers and to innovate their services. One of the innovations made by the Directorate General of Taxes is to make changes to the administration of tax reporting to overcome various tax problems regarding the existence of an Individual Taxpayer who lacks the awareness to comply in terms of submitting Annual Tax Returns.

Therefore, to improve taxpayer compliance, the Directorate General of Tax always seeks to optimize services so that it is expected to increase public awareness and desire to be orderly as a taxpayer, one of them by carrying out tax reforms. Tax reform covers two areas, namely tax policy reform in the 


\section{EPRA International Journal of Research and Development (IJRD)}

form of tax regulations or regulations such as tax laws and tax administration reforms.

Tax administration reform has several purposes. First, providing services to the public in fulfilling their tax obligations. Second, to administer tax revenue so that the transparency and accountability of revenues as well as the expenditure of funds from tax payments can be known at any time. Third, provide an oversight of the implementation of tax collection, especially for tax collectors, taxpayers, or the taxpayers. In order to achieve these objectives, the tax administration reform program needs to be designed and implemented in a comprehensive and comprehensive manner through changes in the areas of organizational structure, business processes and information and communication technology, human resource management, and implementation of good governance.

One of the changes made is to improve business processes by utilizing information and communication technology by implementing an efilling system. Through Decree of the Director General of Tax No. Kep-88/PJ/2004 in May 2004 the e-filling product was officially launched. Precisely in January 2005 at the Presidential Office, the President of the Republic of Indonesia together with the Directorate General of Taxes launched an e-filling or electronic filling system product.

E-filling is a service for filling and submitting Taxpayer Tax Returns electronically through a realtime online system to the Directorate General of Taxes via the internet on the website of the Directorate General of Taxes or through Application Service Providers that have been designated by the Directorate General of Taxes. With the implementation of the e-filling system, it is expected to provide comfort and convenience for taxpayers in preparing and submitting tax returns as they can be sent anytime and anywhere so as to minimize the costs and time spent by taxpayers for calculating, filling and submitting tax returns.

E-filling can minimize costs and time because only by using an internet-connected computer, submission of tax returns can be done anytime, namely 24 hours a day and 7 days a week (including holidays) and anywhere without the need to come to the tax office to give it to Revenue officer. The implementation of the e-Filling system is expected to facilitate taxpayers in submitting tax returns. But in reality, there are still many taxpayers who have not used the facility.

Various studies on the application of the eFilling system to taxpayer compliance have been carried out such as research by Putra et al, (2015); Widilestariningtyas, (2014); Gustiyani, (2015); and Astutu, (2015) showed that the application of e-Filing had a significant effect on taxpayer compliance. This is in line with research by Awaloedin \& Maulana (2018), which states that the application of e-Filing has a significant effect on taxpayer compliance. While research conducted by Handayani and Tambun (2016) shows that the application of the e-Filing system has no significant effect on taxpayer compliance.

Knowledge taxation is the process of changing attitudes and behavior of taxpayers or taxpayer groups in an effort to mature humans through training efforts (Anwar, 2015). Having good tax knowledge can help improve taxpayer compliance with the importance of paying taxes and taxpayers can do it according to tax legislation. If taxpayers do not have knowledge about the regulations and taxation processes, then taxpayers cannot determine their behavior correctly (Tabun, 2016). This is according to Tambun's research (2016) which states that taxpayer knowledge has a significant effect on taxpayer compliance. In contrast to research Hardiningsih et al (2011) and Susanto (2013) which states the knowledge of tax regulations does not affect the willingness to pay taxes.

The inconsistency of the results of previous studies has encouraged the writer to add Account Representative service variables as intervening or mediating variables. Because according to Richard Burton (in the Official, 2011), Account Representative is a tax officer specifically monitors the compliance of tax payments for each taxpayer he supervises (such as Tax Payer Profile/company profile), helping to speed up the process of requesting documents required by taxpayers, monitoring settlement tax audit and objection process and answer taxpayer questions on tax issues and inform the latest tax provisions. So the better the services provided by the Account Representative will increase taxpayer compliance to pay taxes.

Based on the background description above, the authors are interested in conducting a study entitled: "The Effect of E-Filing Systems and Taxation Knowledge on Taxpayer Compliance with Account Representative Services as Mediation Variables (Case Study on Personal Taxpayers at KPP Pratama, East Tangerang)".

\section{LITERATURE REVIEW Compliance Theory}

The theory of compliance according to the science of sociology and psychology is a theory that emphasizes a process of socialization in influencing one's compliance behavior (Saleh, 2004 in Rusmadi, 2017). In the field of taxation, compliance tends to be due to a necessity to pay taxes because the notion of taxation itself is a contribution to the forced state. The legitimacy commitment has not yet been fully implemented because the current tax regulations are still many gaps that become gray areas. Taxpayers realize they have to pay taxes, but through tax management striving to pay taxes to a minimum by 


\section{EPRA International Journal of Research and Development (IJRD)}

utilizing the loopholes in tax law leeway. Compliance with taxes can be interpreted that taxpayers are obliged to obey tax laws. According to Priantara (2016), with the promulgation of all tax laws in the State Gazette and Provisions on Taxation Regulations in the State Gazette means that the public (Taxpayers) must be aware and active in finding out the contents and purpose of the provisions of the taxation laws.

According to Nasucha (2004 in Rusmadi, 2017), compliance of taxpayers can be identified from the compliance of taxpayers in registering themselves, compliance to remit returns (SPT), compliance in calculating and paying tax payable, and compliance in arrears payments.

\section{E-Filing System}

The definition of e-Filing has a difference between one definition with another, one definition is "The use of internet technology, the World Wide Web and tax software for a wide range of tax administration and compliance purposes" (Lai, et al in Ricky et al., 2014). E-Filing is an information system application where citizens interact with complex IT systems. In terms of service to the public, e-Filing provides an important dimension to e-Government services in the field of tax administration, namely services that utilize the speed and effectiveness of costs through the internet. (Sharma \& Yurcik, in Ricky, et al, 2014).

In simple terms e-Filing is an implementation of e-Government application in tax administration especially in SPT reporting, e-Filing has been used in several countries to support the existing taxation system. There are 2 methods of approaching the eFiling system, namely Interactive Filing and Batch Filing (Sharma \& Yurcik in Ricky, et al, 2014). In Interactive Filing, taxpayers interact directly with web-based applications to complete tax reporting online.

In this interactive method there are 2 alternative technologies used, namely: 1). Taxpayers interact directly with the web server hosted by the tax authority or by a third party who is a partner of the tax authority. 2). Taxpayers download software that contains electronic forms for charging tax payable, taxpayers fill out files offline then connect to the eFiling website to send the information files that have been filled.

Reform and modernization of tax administration is expected to increase the taxpayer's trust in the Directorate General of Tax institutions, which in turn will increase taxpayer compliance in carrying out its tax obligations so that it is expected that the tax gap is the difference between the level of actual tax revenue and potential tax revenue getting smaller. This is in accordance with the main objective of the tax collection institution, namely achieving tax revenue with optimal tax effort. Some determinants that affect the willingness of taxpayers to make tax payments voluntarily, viz:

a. Effectiveness of tax administration.

b. Macroeconomic considerations such as interest rates and inflation rates.

c. The low cost of compliance with the existing taxation system.

d. Fairness and fairness felt by taxpayers.

e. Simplicity of provisions, procedures and procedures.

f. The quality of tax administration services to the taxpayer community.

g. Can be accounted for money from the taxpayer community.

Demands for services that are fast, easy, cheap and accurate are the expectations of the community, by the Directorate General of Taxes these service demands are responded to with the modernization of tax administration, tax administration modernization done by DGT basically includes (Pandiangan, 2008 in Ricky. Et al, 2014): ( 1). Organizational restructuring, (2). Improving business processes through the use of communication and information technology, (3). Improving human resource management.

Improving services to taxpayers in submitting notification (SPT), the Directorate General of Taxes has developed the SPT reporting system with eFiling. The e-Filing system is a continuation of the submission of SPT in electronic form SPT or known as e-SPT. E-Filing was built at the end of 2004 and was inaugurated in 2005 by President Susilo Bambang Yudhoyono. After the inauguration of the e-Filing, the Directorate General of Taxes held a socialization to the Taxpayers in all Regional Offices. The continued development of e-Filing was carried out in 2009. From the action plan of the Directorate General of Taxes there was no plan for further development and socialization of e-Filing in the future.

\section{Taxation Knowledge}

Knowledge is the result of human knowing about something, or all human actions to understand a certain object that can be either tangible goods through reason, can also be understood as an ideal object of human form, or concerned with psychological problems. Taxes are people's contributions to the state treasury based on the law (which can be forced) by not getting lead services that can be directly shown and which are used to pay public expenses (Mardiasmo, 2016). So in conclusion, tax knowledge is the ability of taxpayers to know tax regulations both about tax rates based on the laws they will pay and tax benefits that will be useful for their lives (Utomo, 2011).

Knowledge of tax regulations is very important to foster compliance. Because how can taxpayers comply if they do not know how the tax regulations. With the knowledge of taxpayers about good tax will be able to minimize the existence of tax evation 


\section{EPRA International Journal of Research and Development (IJRD)}

(Witono, 2008 in Nurulita, 2017). With the knowledge of taxation will help taxpayer compliance in paying taxes, so the level of compliance will increase. Taxpayers who are knowledgeable about taxes, will self-consciously be obedient to pay taxes. They already know how the tax revenue flow will work, until finally the benefits of paying the tax are felt. A taxpayer will obey pay taxes if the taxpayer has knowledge of taxation well. If the taxpayer knows the tax regulations, then the taxpayer will obey his tax obligations and will increase taxpayer compliance.

\section{Taxpayer Compliance}

According to the Big Indonesian Dictionary, the term obedience means obedience, obedience. Compliance is the motivation of a person, group or organization to act according to established rules (Fajriyan, 2015). In tax, the rule that applies is taxation law. Tax compliance is a person's compliance, in this case is a taxpayer, to tax regulations or laws (Tiraada, 2013).

Based on the Regulation of the Minister of Finance of the Republic of Indonesia No. 74/PMK.03/2012 concerning the procedure for determining taxpayers with certain criteria in the framework of returning the overpayment of tax overpayments Chapter II article 2, compliant taxpayers are those who meet four criteria, namely: (1) timely submitting a notice for all types of taxes, (2) have no tax arrears, except tax arrears that have obtained permission to pay in installments or postpone tax payments, (3) financial statements audited by a public accountant or government financial oversight body with a reasonable opinion without exception for 3 (three) years and (4) has never been convicted of a criminal offense in the taxation field based on a court decision which has had permanent legal force in the last 5 (five) years.

The issue of compliance becomes important because non-compliance together will lead to efforts to avoid taxes which results in reduced depositing of tax funds into the state treasury. So the higher the truth count and calculate. the accuracy of depositing, and filling and submitting taxpayers' notification, it is expected that the higher level of taxpayer compliance in implementing and fulfilling their tax obligations.

\section{Account Representative}

Menururt KMK No. 98/KMK.01/2006 concerning Account Representatives at Tax Service Offices that Have Implemented Modern Organizations, article 1 paragraph 2 reads, what is meant by Account Representatives are employees appointed to each Supervision and Consultation Section at the Tax Service Office that has implemented the Modern Organization. In article 2 paragraph 1 explained, the Account Representative has a duty; supervise taxpayers' tax compliance, guidance/appeal and tax technical consultation to taxpayers, compile taxpayer profiles, analyze taxpayer performance, reconcile taxpayer data in the context of intensification and evaluate the results of appeals based on applicable regulations. From the explanation of this function, the first thing to underline is the word "Supervision" and the second is the word "Consultation" which is done by the same person.

Account Representative (AR) has a duty:

a. Supervise tax compliance for taxpayers;

b. Tax guidance/appeal and technical consultation to taxpayers;

c. Compilation of taxpayer profiles;

d. Analysis of taxpayer performance, reconciliation of taxpayer data in the context of intensification; and Evaluate the results of appeals based on applicable regulations.

Minister of Finance Bambang P.S. Brodjonegro on April 302015 signed the Minister of Finance Regulation Number: 79/PMK.01/2015 concerning Account Representatives at the Tax Service Office. The Minister of Finance Regulation number 79/PMK.01/2015 also simultaneously revokes the Minister of Finance Regulation number 68/PMK.01/2008 concerning Amendments to the Decree of the Minister of Finance Number: 98/KMK.01/2006 concerning Account Representatives at the Tax Office implementing Modern Organizations. In PMK number: 79/PMK.01/2015 concerning Account Representatives at the Tax Service Office (KPP) making a separation in the Account Representative position so that now the Account Representative consists of:

a. Account Representative who carries out Taxpayer's service and consultation functions, which is located in Waskon I Section;

Account Representatives who carry out taxpayer service and consulting functions have the task:

1) Carrying out the process of completing the Taxpayer's application;

2) Carrying out the process of settling the proposed correction of tax assessments;

3) Conducting technical guidance and tax consulting to taxpayers; and

4) Carry out the process of completing the proposed reduction in Land and Building Tax.

b. Account Representative who carries out the functions of Supervising and Excavating Potential Taxpayers, located in Waskon II, Waskon III and Waskon IV Sections.

Account Representatives who carry out the function of supervision and excavation of potential Taxpayers have the task:

1) Monitor the taxpayer's compliance with tax obligations;

2) Compiling taxpayer profiles; 


\section{EPRA International Journal of Research and Development (IJRD)

3) Analysis of the performance of taxpayers; and

4) Reconciliation of Taxpayer data in the context of intensification and appeal to Taxpayers.

Increasing the trust of taxpayers towards Account Representatives will make taxpayers more open in consultation with Account Representatives. If taxpayers are more open, Account Representatives can guide taxpayers in fulfilling their tax obligations. For example, when there is a new format, the Account Representative can guide taxpayers in the procedure for filling out the form. With the guidance of the Account Representative, taxpayers will be easier to meet their tax obligations.

\section{Previous Research Review}

Previous studies that can support this research are as follows: Ricky, et al (2014) in his research entitled "Analysis of Factors Affecting Taxpayer Behavior to Use E-Filing". The results of this study indicate that the perception of experience has a significant effect, the perception of security and confidentiality has a significant effect, and the perception of speed does not significantly influence the behavior of e-Filing usage on corporate taxpayers in Manado.

Amalia (2016) in her study entitled "The Effect of E-Filing Implementation on the Compliance Level of Annual Tax Returns for Personal Taxpayers Income Tax with Account Representative Services as Intervening Variables in Palembang City". The results showed that the Account Representative service was able to mediate the e-Filing implementation variable to the compliance of individual taxpayers in submitting SPT. Account
Representative services in serving and providing an important role for the ease of reporting taxation affect tax revenue and taxpayer compliance.

Suprayoga and Hasymi (2018) in their study entitled "The Effect of E-Filing System Implementation on the Compliance of Individual Taxpayers with Internet Understanding as Moderation Variables at the Jakarta Jatinegara Primary Tax Service Office". The results of the study showed that the adoption of the e-filing system had a positive and significant effect on the compliance of individual taxpayers. Understanding the internet is a pure moderator and has a positive influence on the relationship between the adoption of the e-filing system with individual taxpayer compliance.

Erwanda, et al. (2019) in his research entitled "The Effect of E-Filing and Tax Knowledge Knowledge on Taxpayer Compliance with Compliance Costs as a Moderation Variable". The results obtained are the application of e-filing has a significant positive effect on taxpayer compliance, tax knowledge does not affect taxpayer compliance, compliance costs are proven to moderate the relationship between e-filing application and taxpayer compliance, and compliance costs are not proven to moderate the relationship between tax knowledge and compliance taxpayer.

\section{Theoretical Thought Framework}

Based on the theoretical basis and some previous research, the framework in this study can be shown by the following picture:

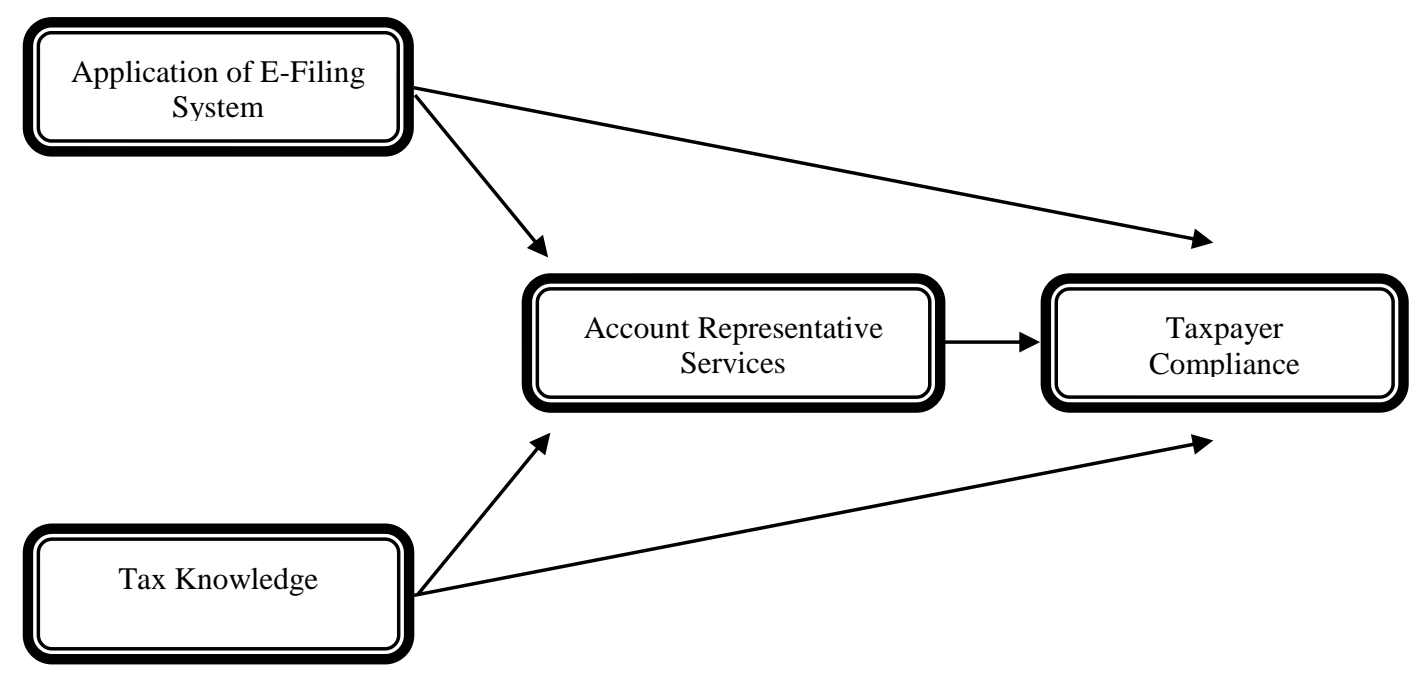

Figure 1.1 Research Model

\section{Research Hypothesis}

From the above thought framework, the researcher draws a hypothesis as follows:

Hal = Application of e-filing system has a positive effect on account representative services
Ha2 $=$ Knowledge of taxation has a positive effect on account representative services $\mathrm{Ha} 3$ = Application of e-filing system has a positive effect on tax compliance 


\section{EPRA International Journal of Research and Development (IJRD)

Ha4 = Tax knowledge has a positive effect on taxpayer compliance

Ha5 $=$ Account representative service has a positive effect on tax compliance

\section{RESEARCH METHODOLOGY Types of research}

This research is causal which will test the hypothesis about the effect of one or several independent variables on the dependent variable. According to Sarwono and Suhayati (2010) causal research is research conducted to identify causal relationships between variables. Causal research is aimed at knowing which variables function as causes (independent variables) and which variables function as results (dependent variables).

\section{Operational Definition and Variable Measurement}

The variables used in this study consisted of the dependent variable and the independent variable. Operational research variables can be summarized in table 1.1.

\section{Table 1.1 Operationalization of Variables}

\begin{tabular}{|c|c|c|c|}
\hline Type Variable & Dimension & Indicator & Skala \\
\hline \multicolumn{4}{|l|}{ Independent } \\
\hline \multirow{3}{*}{$\begin{array}{l}\text { Implementation } \\
\text { of e-filing } \\
\text { system (Lai, } \\
\text { Obid dan } \\
\text { Meera, 2004) }\end{array}$} & $\begin{array}{l}\text { - Performance } \\
\text { expectacy, }\end{array}$ & - I always use e-Filing whenever I report taxes & \multirow[t]{3}{*}{ Interval } \\
\hline & - Effort expectacy, & $\begin{array}{l}\text { - I will always use e-Filing to report taxes because it } \\
\text { has features that help my work }\end{array}$ & \\
\hline & - Social expectacy. & - I intend to continue using e-Filing in the future & \\
\hline Tax Knowledge & $\begin{array}{l}\text { The process by which } \\
\text { taxpayers know } \\
\text { about taxation and } \\
\text { apply that knowledge } \\
\text { to pay taxes }\end{array}$ & $\begin{array}{l}\text { - Taxpayer knowledge of the tax function } \\
\text { - Taxpayer knowledge of tax regulations } \\
\text { - Taxpayer knowledge of registration as taxpayer } \\
\text { - Taxpayer Knowledge of Tax Payment Procedures } \\
\text { - Taxpayer knowledge of tax rates }\end{array}$ & Interval \\
\hline \multicolumn{4}{|l|}{ Dependent } \\
\hline \multirow[t]{3}{*}{$\begin{array}{c}\text { Taxpayer } \\
\text { compliance } \\
\text { (Suryadi, 2006) }\end{array}$} & - Tax audits & $\begin{array}{l}\text { - With the changes made by the Directorate General } \\
\text { of Taxes, registration of Taxpayers to obtain } \\
\text { NPWP can now be done easily, making it easier for } \\
\text { Taxpayers to carry out their obligations. }\end{array}$ & \multirow[t]{3}{*}{ Interval } \\
\hline & - Law enforcement & $\begin{array}{l}\text { - The application of strict sanctions for violations } \\
\text { by taxpayers increases the compliance of } \\
\text { taxpayers to substantively meet all material tax } \\
\text { provisions. }\end{array}$ & \\
\hline & - Tax compensation & $\begin{array}{l}\text { - Administrative reforms undertaken by the } \\
\text { Directorate General of Taxes with the use of } \\
\text { information technology facilitate reporting of tax } \\
\text { returns, thus encouraging taxpayers to report } \\
\text { before the deadline ends } \\
\text { - Tax obligations that can be paid easily, increase } \\
\text { taxpayer compliance to carry out obligations } \\
\text { before the deadline expires. } \\
\text { - Increasing the quality and integrity of the tax } \\
\text { apparatus, encourages taxpayers to fill SPT } \\
\text { honestly. }\end{array}$ & \\
\hline \multicolumn{4}{|l|}{ Intervening } \\
\hline \multirow{4}{*}{$\begin{array}{l}\text { Account } \\
\text { Representative } \\
\text { services }\end{array}$} & \multirow{4}{*}{$\begin{array}{l}\text { Account } \\
\text { representative tasks } \\
\text { related to taxpayers }\end{array}$} & - Oversight & \multirow[t]{4}{*}{ Interval } \\
\hline & & - Guidance & \\
\hline & & - Create and update WP profiles & \\
\hline & & - Analyzing SPT & \\
\hline
\end{tabular}

\section{Variable Measurement}

The research instrument was in the form of a questionnaire compiled based on the research indicators of each variable so that there were 4 (four) questionnaires in this study, namely the e-filing system questionnaire, tax knowledge knowledge questionnaire, account representative service questionnaire, and taxpayer compliance questionnaire. The questionnaire was arranged using an interval scale using five answer choices as follows: Strongly Agree = given a score of 5 Agree Hesitation Disagree Strongly Disagree
$=$ given a score of 4 $=$ given a score of 3 $=$ given a score of 2 $=$ given a score of 1 


\section{EPRA International Journal of Research and Development (IJRD)

\section{Population and Research Samples}

The population of this research is all individual taxpayers who are registered at KPP Pratama, East Tangerang.

Sampling in this study was conducted using purposive sampling method. The data obtained by researchers from KPP Pratama, East Tangerang, researchers obtained the number of individual taxpayers as much as 158,563 taxpayers. From a population that is clearly known, the calculation of sampling using the Slovin formula is as follows:

$n=\frac{N}{1+N e^{2}}$

$n=\frac{158.563}{1+158.563(10 \%)^{2}}$

$n=\frac{158.563}{1.586,63}$

$n=99,937$, rounded to 100

Based on these calculations the number of samples in this study were 100 Individual Taxpayers registered at KPP Pratama, East Tangerang.

\section{Data Types and Sources}

The type of data in this study is primary data obtained from respondents' responses to the questionnaire sent, while the source of the data comes from individual taxpayer answers registered at KPP Pratama, East Tangerang.

\section{Data collection technique}

The method of data collection in this study was carried out by the sampling method, which is a method of investigation conducted to obtain facts or symptoms that exist and look for information factually. Data collection was carried out through a questionnaire given to individual taxpayers registered at the KPP Pratama, East Tangerang. The questionnaire contains questions that represent each variable in this study.

\section{Analysis Method Descriptive statistics}

Descriptive statistics in this study are used to provide a description of the character of the research variable using a frequency distribution table that shows the mode number, the range of scores and the standard deviation.

\section{Data Quality Test}

According to Hair et. al (1996, in Sandjojo, 2011), the quality of data generated from the use of research instruments can be evaluated through reliability and validity tests. The tests are each to determine the consistency and accuracy of data collected from the use of the instrument.

\section{Test Prerequisite Analysis}

To be able to use path analysis in hypothesis testing, it is necessary to first test statistical prerequisites for the data. The analysis prerequisite tests include tests of normality, homogeneity, and significance and linearity.

\section{Hypothesis testing}

The design of hypothesis testing used in this study is to use path analysis and Sobel Test. According to Imam Ghozali (2013) to calculate the path coefficient through the following work steps: 1). Draw a path diagram that explains the relationship between variables that reflect the proposed conceptual hypothesis, 2). Calculate the amount of influence (structural parameters) between a cause variable and an effect variable.

The path analysis method used in this study is explained in the figure as follows:

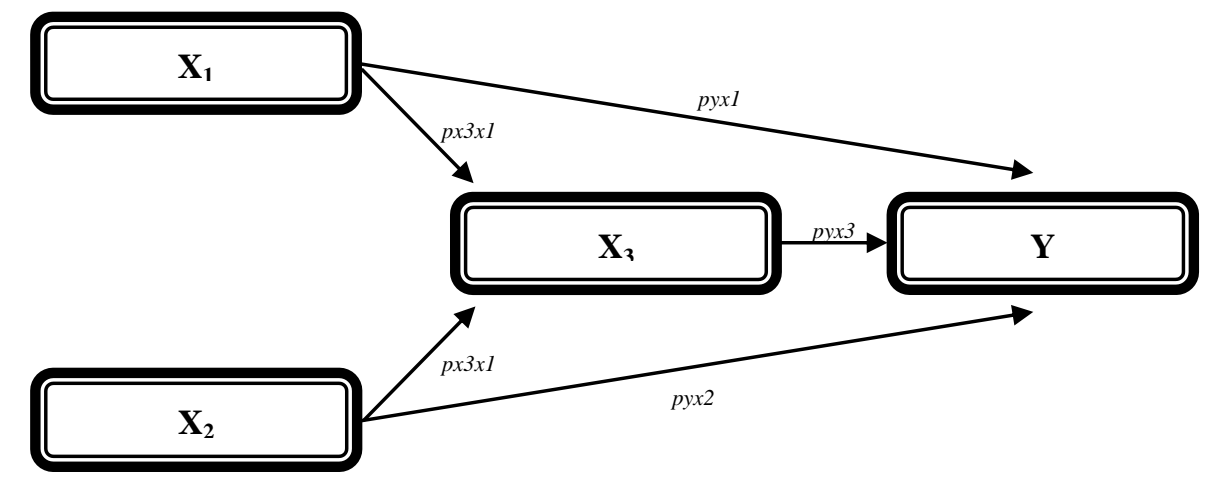

Figure 1.2 Path Diagram Structure

The regression model in this research is:

$\mathrm{X}_{3}=\alpha+\rho_{x 3 x 1} \mathrm{X}_{1}+\rho_{x 3 \times 2} \mathrm{X}_{2}+\varepsilon_{1}$

(Substruktural 1)

$\mathrm{Y}=\alpha+\rho_{y X 1} \mathrm{X}_{1}+\rho_{y x 2} \mathrm{X}_{2}+\rho_{y x 3} \mathrm{X}_{3}+\varepsilon_{2}$

(Substruktural 2)

Dimana :

$\mathrm{Y}=$ Taxpayer Compliance

$\mathrm{X}_{1}=$ Implementation of e-filing system

$\mathrm{X}_{2}=$ Tax Knowledge 


\section{EPRA International Journal of Research and Development (IJRD)

$\mathrm{X}_{3}=$ Account representative services

$p=$ Path coefficient

$\varepsilon=$ Error

In this study the significance level ( $\alpha)$ of 0.05 or $5 \%$ was used. This multiple regression analysis is carried out with the help of the SPSS (Statistical Package For Social Sciences) Release 25.0 for Windows program so that the coefficient of determination, the statistical $F$ value and the $t$ statistical value used in hypothesis testing can be obtained.

\section{Sobel test and Bootstrapping test.}

Sobel test is done by testing the strength of the indirect effect of the independent variable $(\mathrm{X})$ to the dependent variable (Y) through the intervening variable $(Z)$.

An alternative approach to test the significance of mediation using bootstrapping techniques. Bootstrapping is a non-parametric approach that does not assume the shape of the variable distribution and can be applied to a small sample size. Heyes and Preacher (2004) in Ghozali (2013) have developed a sobel and bootstrapping test in the form of SPSS

script 25 . The hypothesis is that exogenous variables individually influence indirectly on endogenous variables. Basis of Decision Making:

1) If the probability is $t>$ ttable, then the hypothesis is accepted.

2) If the probability is tcount $<$ ttable, then the hypothesis is rejected. (Ghozali, 2013)

\section{RESEARCH RESULTS AND DISCUSSION \\ Research Data Description}

Descriptive analysis is calculated based on the percentage of respondents' answers to the research questions by using the mean value of each indicator proposed to describe the perceptions of all respondents. Based on the mean (mean), then the respondents' perceptions are interpreted using the three-box method criteria (Ferdinand, 2006), which are: $10.00-40=$ low, $40.01-70=$ moderate, and $70.01-100=$ high.

Table 1.2 Descriptive Statistics Results

\begin{tabular}{|l|c|c|c|c|c|}
\hline \multicolumn{1}{|c|}{ Variabel } & $\begin{array}{c}\text { Indeks } \\
\text { Value }\end{array}$ & Minimum & Maksimum & Mean & $\begin{array}{c}\text { Std. } \\
\text { Deviation }\end{array}$ \\
\hline Implementation of e-filing system & 68,47 & 40 & 60 & 51,36 & 5,262 \\
\hline Tax Knowledge & 77,33 & 12 & 25 & 19,33 & 3,362 \\
\hline Account Representative services & 82,29 & 24 & 33 & 28,80 & 2,423 \\
\hline Taxpayer compliance & 83,94 & 30 & 44 & 37,59 & 3,451 \\
\hline
\end{tabular}

Source: Primary data processed

The following are descriptive statistical results about the research variables as follows: The e-Filing system implementation variable has a minimum value of 40 and a maximum value of 60 . The average eFiling system implementation variable is 51.36 with a standard deviation of 5.262. While the frequency index value of 68.47. With a frequency index value of 68.47 , it can be concluded that the perception of respondents' answers to the variable implementation of the e-Filing system is in the moderate category, because it is in the range of values between 40.01 70 .

The tax knowledge variable has a minimum value of 12 and a maximum value of 25 . The average tax knowledge variable is 19.33 with a standard deviation of 3.362. While the frequency index value of 77.33. With a frequency index value of 77.33, it can be concluded that the perception of respondents' answers to the tax knowledge variable is in the high category, because it is in the range of values between $70.01-100$.

The Account Representative service variable has a minimum value of 24 and a maximum value of 33 . The average Account Representative service variable is 28.80 with a standard deviation of 2.423 . While the frequency index value of 82.29 . With a frequency index value of 82.29 , it can be concluded that the perception of respondents' answers to the Account Representative service variable is in the high category, because it is in the range of values between $70.01-100$.

The taxpayer compliance variable has a minimum value of 30 and a maximum value of 44 . The average taxpayer compliance variable is 37.59 with a standard deviation of 3.451. While the frequency index value of 83.94 . With a frequency index value of 83.94 , it can be concluded that the perception of respondents' answers to taxpayer compliance variables is in the high category, because it is in the range of values between 70.01 - 100 .

\section{Data Quality Test Validity test}

This test is intended to measure the validity of a questionnaire in measuring a contract. And at the same time strengthen the results of previous calculations that all variables measured using the Likert scale can be used for further data processing. 


\section{EPRA International Journal of Research and Development (IJRD)}

Volume: 5 | Issue: 10 | October 2020

- Peer Reviewed Journal

Validation Test Results for each variable can be seen in the following table:

Table 1.3 Validity Test Results

\begin{tabular}{|c|c|c|c|}
\hline Variable & $\begin{array}{c}\text { No. } \\
\text { Item }\end{array}$ & $\begin{array}{c}\text { Correlation } \\
\text { Value } \\
\end{array}$ & Status \\
\hline \multirow{15}{*}{ Implementation of e-filing system } & Q1 & 0,638 & Valid \\
\hline & Q2 & 0,690 & Valid \\
\hline & Q3 & 0,613 & Valid \\
\hline & Q4 & 0,652 & Valid \\
\hline & Q5 & 0,608 & Valid \\
\hline & Q6 & 0,745 & Valid \\
\hline & Q7 & 0,631 & Valid \\
\hline & Q8 & 0,608 & Valid \\
\hline & Q9 & 0,717 & Valid \\
\hline & Q10 & 0,625 & Valid \\
\hline & Q11 & 0,642 & Valid \\
\hline & Q12 & 0,660 & Valid \\
\hline & Q13 & 0,619 & Valid \\
\hline & Q14 & 0,540 & Valid \\
\hline & Q15 & 0,553 & Valid \\
\hline \multirow{5}{*}{ Tax Knowledge } & Q16 & 0,784 & Valid \\
\hline & Q17 & 0,726 & Valid \\
\hline & Q18 & 0,838 & Valid \\
\hline & Q19 & 0,760 & Valid \\
\hline & Q20 & 0,607 & Valid \\
\hline \multirow{7}{*}{ Account Representative services } & Q21 & 0,635 & Valid \\
\hline & Q22 & 0,753 & Valid \\
\hline & Q23 & 0,651 & Valid \\
\hline & Q24 & 0,640 & Valid \\
\hline & Q25 & 0,658 & Valid \\
\hline & Q26 & 0,674 & Valid \\
\hline & Q27 & 0,635 & Valid \\
\hline \multirow{9}{*}{ Taxpayer compliance } & Q28 & 0,541 & Valid \\
\hline & Q29 & 0,621 & Valid \\
\hline & Q30 & 0,699 & Valid \\
\hline & Q31 & 0,761 & Valid \\
\hline & Q32 & 0,736 & Valid \\
\hline & Q33 & 0,678 & Valid \\
\hline & Q34 & 0,676 & Valid \\
\hline & Q35 & 0,588 & Valid \\
\hline & Q36 & 0,677 & Valid \\
\hline
\end{tabular}

Source: Primary data processed

\section{Reliability test}

The reliability test is carried out with reference to Cronbach Alpha 0.60. Table 1.4 shows that all instruments of the tested variables have Cronbach alpha above 0.60 , so the test results are quite satisfactory because all instruments have a high level of reliability, so they can be used for further data processing. The reliability test results of each variable can be seen in the following table:

Table 1.4 Reliability test results

\begin{tabular}{|c|l|c|c|}
\hline No & \multicolumn{1}{|c|}{ Variable } & $\begin{array}{c}\text { Koefisien } \\
\text { Cronbach Alpha }\end{array}$ & $\begin{array}{c}\text { Number of } \\
\text { Instruments }\end{array}$ \\
\hline 1 & Implementation of e-filing system & 0,893 & 15 \\
\hline 2 & Tax Knowledge & 0,797 & 5 \\
\hline 3 & Account Representative services & 0,719 & 7 \\
\hline 4 & Taxpayer compliance & 0,933 & 9 \\
\hline
\end{tabular}




\section{EPRA International Journal of Research and Development (IJRD)

\section{Test Prerequisite Analysis Normality test}

Testing for normality using the Lilliefors test. Provisions in the error test are if the statistic L count $<$ L table $(\alpha=0.05)$, then the error data is normally distributed. But if $\mathrm{L}$ count $>\mathrm{L}$ table $(\alpha=0.05)$, then the data is not normally distributed.

Thus the overall results of the normality test calculation using the Lilliefors test can be seen in the summary in Table 1.5 .

Table 1.5 Test summary normality

\begin{tabular}{|c|c|c|c|c|c|c|}
\hline \multirow{2}{*}{ No } & \multirow{2}{*}{$\begin{array}{c}\text { Error } \\
\text { estimated }\end{array}$} & \multirow{2}{*}{$\mathbf{n}$} & \multirow{2}{*}{$\mathbf{L}_{\text {Count }}$} & \multicolumn{2}{|c|}{$L_{\text {Table }}$} & \multirow{2}{*}{ Decision } \\
\hline & & & & $\alpha=0.05$ & $\alpha=0.01$ & \\
\hline 1 & $\mathrm{X} 3$ atas X1 & 90 & $-0,0653$ & 0,0934 & 0,1087 & Normal \\
\hline 2 & X3 atas X2 & 90 & $-0,1052$ & 0,0934 & 0,1087 & Normal \\
\hline 3 & $\mathrm{Y}$ atas X1 & 90 & $-0,0892$ & 0,0934 & 0,1087 & Normal \\
\hline 4 & Y atas X2 & 90 & $-0,1046$ & 0,0934 & 0,1087 & Normal \\
\hline 5 & Y atas X3 & 90 & $-0,1022$ & 0,0934 & 0,1087 & Normal \\
\hline
\end{tabular}

\section{Homogeneity Test}

Another requirement for using path analysis is that the verifiable variance bound to the independent variable must be homogeneous. Homogeneity variance testing is done through SPSS and Excel using the Barlett test. A homogeneous variance if produced when count 2 count $<\chi^{2}$ table. Thus the overall results of the homogeneity test percountan can be seen in the summary in the following table:

Table 1.6 test summaries of homogeneity

\begin{tabular}{|c|c|c|c|c|c|}
\hline No & $\begin{array}{c}\text { Error } \\
\text { estimated }\end{array}$ & $\mathbf{X}_{\mathbf{h}}$ & $\mathbf{d f}$ & $\mathbf{X}_{\mathbf{t}}$ & Decision \\
\hline 1 & $\mathrm{X} 3$ atas X1 & 11,470 & 71 & 91,670 & Homogen \\
\hline 2 & $\mathrm{X} 3$ atas X2 & 9,628 & 76 & 97,351 & Homogen \\
\hline 3 & Y atas X1 & 12,146 & 71 & 91,670 & Homogen \\
\hline 4 & Y atas X2 & 17,109 & 76 & 97,351 & Homogen \\
\hline 5 & Y atas X3 & 11,157 & 80 & 101,879 & Homogen \\
\hline
\end{tabular}

\section{Test Path Analysis}

Path analysis is used to analyze the pattern of relationships between variables with the aim of finding out the direct and indirect effects of a set of independent (exogenous) variables on the dependent variable (endogenous). From the data processing through the SPSS program the following results were obtained:

Table 1.7 Path Analysis Results

\begin{tabular}{|c|c|c|c|c|c|c|c|}
\hline Description & $\rho$ & $\mathbf{T}_{\text {count }}$ & Sig & $\mathbf{T}_{\text {Table }}$ & $\mathbf{R}^{2}$ & $F_{\text {count }}$ & Sig \\
\hline Sub-Struktur 1 & & & & \multirow{3}{*}{1,663} & \multirow{3}{*}{0,613} & \multirow{3}{*}{68,880} & \multirow{3}{*}{0,000} \\
\hline $\begin{array}{l}\text { Implementation of e-filing } \\
\text { system }\end{array}$ & 0,421 & 5,553 & 0,000 & & & & \\
\hline Tax Knowledge & 0,490 & 6,466 & 0,000 & & & & \\
\hline Sub-Struktur 2 & & & & \multirow{4}{*}{1,663} & \multirow{4}{*}{0,816} & \multirow{4}{*}{$\begin{array}{c}126,84 \\
7\end{array}$} & \multirow{4}{*}{0,000} \\
\hline $\begin{array}{l}\text { Implementation of e-filing } \\
\text { system }\end{array}$ & 0,427 & 6,974 & 0,000 & & & & \\
\hline Tax Knowledge & 0,166 & 2,590 & 0,011 & & & & \\
\hline Account Representative services & 0,439 & 5,905 & 0,000 & & & & \\
\hline
\end{tabular}

Source: Primary data processed

Based on the results of the path analysis in SubStructure 1, the path coefficients $\mathrm{X} 1$ and $\mathrm{X} 2$ to $\mathrm{X} 3$ are obtained $\rho \times 3 \times 1=0.421$ and $\rho \times 3 \times 2=0.490$. While the coefficient of determination or contribution of X1 and X2 to X3 is (Rsquare) $=0.613$ as in Table 1.7 , which means that $61.3 \%$ of Account
Representative services can be explained by variations in the variables of e-Filing system implementation and tax knowledge. The amount of residual coefficient $(\rho \times 3 \mathcal{E} 1)=\sqrt{ } 1-0.613=0.622$ is the influence of other variables beyond the application of e-Filing systems and tax knowledge. 


\section{EPRA International Journal of Research and Development (IJRD)}

While the results of the path analysis in SubStructure 2 obtained path coefficients X1, X2 and X3 against $Y$ of $\rho y x 1=0.427$, $\rho y x 2=0.166$ and $\rho y x 3=$ 0.439 . While the coefficient of determination or contribution of $\mathrm{X} 1, \mathrm{X} 2$ and $\mathrm{X} 3$ to $\mathrm{Y}$ is (Rsquare) = 0.816 as in Table 1.7 , which means that $81.6 \%$ of taxpayer compliance can be explained by the implementation of e-filing system, tax knowledge, and account representative services. The amount of residual coefficient $(\rho y \varepsilon 2)=\sqrt{ } 1-0,816=0.429$ is the influence of other variables beyond the implementation of e-filing system, taxation knowledge, and account representative services. The results of the path coefficients in sub-structure 1 and sub-structure 2 produce the structural equation, as follows:

$$
\begin{aligned}
& \mathrm{X}_{3}=0,421 \mathrm{X}_{1}+0,490 \mathrm{X}_{2}+0,622 \varepsilon_{1} \text { dan } \mathrm{R}^{2} \times 3 \times 2 \times 1= \\
& \quad 0,613 \\
& \mathrm{Y}=0,427 \mathrm{X}_{1}+0,166 \mathrm{X}_{2}+0,439 \mathrm{X}_{3}+0,429 \varepsilon_{2} \text { dan } \\
& \mathrm{R}_{\mathrm{y} \times 3 \times 2 \times 1}^{2}=0,816
\end{aligned}
$$

\section{Hypothesis test}

After testing the model, then testing the hypothesis to determine the direct and indirect effects between variables. The hypothesis proposed will be concluded by counting the value of the path coefficient and the significance of each path studied. The results of the decision on the proposed hypothesis are explained as follows:

1. The implementation of e-filing system has a direct effect on the account representative service

Based on the calculation results, it can be seen that the path coefficient $(\mathrm{p} \times 3 \times 1)$ is 0.421 with tcount $=5.553$, at $\alpha=0.05$, it is obtained ttable $=1.663$. Because the value of tcount $=$ 5.553 is greater than ttable $=1.663$, the path coefficient is significant. The results showed that the implementation of e-filing system had a direct effect on the account representative service of $(0.421 \times 0.421 \times 100 \%)=17.72 \%$. Thus Ha1 received.

2. Tax knowledge has a direct effect on the account representative service

Based on the accounting results it can be seen that the value of the path coefficient $(\mathrm{p} \times 3 \times 2)$ of 0.490 with tcount $=6.466$, at $\alpha=0.05$, obtained ttable $=1.663$. Because the value of tcount $=6.466$ is greater than ttable $=1.663$, the path coefficient is significant. The results showed that tax knowledge directly affected the account representative service for $(0.490 \times 0.490 \times 100 \%)$ $=24.01 \%$. Thus Ha2 received.

3. The implementation of e-filing system has a direct effect on the compliance of taxpayers

Based on the accounting results it can be seen that the path coefficient value (pyx1) of 0.427 with tcount $=6.974$, at $\alpha=0.05$, obtained ttable $=1.663$. Because the value of tcount $=$ 6.974 is greater than ttable $=1.663$, the path coefficient is significant. The results showed that the implementation of e-filing system had a direct effect on taxpayer compliance by $(0.427 \times 0.427$ x $100 \%)=18.23 \%$. Thus $\mathrm{Ha} 3$ received.

4. Tax knowledge directly affects the compliance of taxpayers

Based on the accounting results it can be seen that the path coefficient value (pyx2) of 0.166 with tcount $=2.590$, at $\alpha=0.05$, obtained ttable $=1.663$. Because tcount $=2.590$ is greater than ttable $=1.663$, the path coefficient is significant. The results showed that tax knowledge has a direct effect on taxpayer compliance by $(0.166 \times 0.166 \times 100 \%)=2.76 \%$. Thus Ha4 received.

5. Account representative services directly affect the compliance of taxpayers

Based on the accounting results it can be seen that the path coefficient value (pyx3) of 0.439 with tcount $=5.905$, at $\alpha=0.05$, obtained ttable $=1.663$. Because the value of tcount $=$ 5.905 is greater than ttable $=1.663$, the path coefficient is significant. The results showed that the account representative service had a direct effect on taxpayer compliance by $(0.439 \times 0.439$ $\mathrm{x} 100 \%)=19.27 \%$. Thus Ha5 was accepted.

\section{Mediation Factor Testing}

To test the significance of the indirect effect, it can be done by comparing the $\mathrm{Z}$ value of the calculated $a b$ coefficient with the Ztable value of 1.96. If the Zcount value is greater than the Ztable value, it can be concluded that there is a mediating effect (Ghozali, 2013). The calculation of mediation factor testing will be explained as follows: 


\section{EPRA International Journal of Research and Development (IJRD)}

Volume: 5 | Issue: 10 | October 2020

- Peer Reviewed Journal

1. The effect of account representative services in mediating the relationship between the adoption of the e-filing system and taxpayer compliance

Table 1.8 Mediation Test Results with the Sobel Test

\begin{tabular}{|c|c|c|c|c|}
\hline \multicolumn{5}{|c|}{ DIRECT AND TOTAL EFFECTS } \\
\hline & Coeff & se & $\mathrm{t}$ & Sig (two) \\
\hline $\mathrm{b}(\mathrm{YX})$ & 0,5198 & 0,0426 & 12,1988 & 0,0000 \\
\hline $\mathrm{b}(\mathrm{MX})$ & 0,3008 & 0,0372 & 8,0968 & 0,0000 \\
\hline $\mathrm{b}(\mathrm{YM} . \mathrm{X})$ & 0,7823 & 0,0899 & 8,7001 & 0,0000 \\
\hline b(YX.M) & 0,2845 & 0,0414 & 6,8718 & 0,0000 \\
\hline \multicolumn{5}{|c|}{ INDIRECT EFFECT And SIGNIFICANCE USING NORMAL DISTRIBUTION } \\
\hline & Value & se & $\mathrm{z}$ & Sig (two) \\
\hline Effect & 0,2353 & 0,0398 & 5,9062 & 0,0000 \\
\hline
\end{tabular}

Source: Primary data processed

Testing the significance of indirect effects with the Sobel test obtained $z=5.9062$ and $p=0.0000$. Because $\mathrm{z}$-value in absolute price $>1.96$ and the level of statistical significance $\mathrm{z}$ (p-value) $<0.05$, it means that there is a mediating effect of account representative services on the relationship between the implementation of the e-Filing system with taxpayer compliance.

2. The effect of account representative services in mediating the relationship between tax knowledge and taxpayer compliance

Table 1.9 Mediation Test Results with the Sobel Test

\begin{tabular}{|c|c|c|c|c|}
\hline \multicolumn{5}{|c|}{ DIRECT AND TOTAL EFFECTS } \\
\hline & Coeff & $\mathrm{se}$ & $\mathrm{t}$ & Sig (two) \\
\hline $\mathrm{b}(\mathrm{YX})$ & 0,6892 & 0,0811 & 8,5005 & 0,0000 \\
\hline $\mathrm{b}(\mathrm{MX})$ & 0,4970 & 0,0556 & 8,9356 & 0,0000 \\
\hline $\mathrm{b}(\mathrm{YM} . \mathrm{X})$ & 1,0041 & 0,1133 & 8,8627 & 0,0000 \\
\hline b(YX.M) & 0,1902 & 0,0816 & 2,3294 & 0,0222 \\
\hline \multicolumn{5}{|c|}{ INDIRECT EFFECT And SIGNIFICANCE USING NORMAL DIS } \\
\hline & Value & se & $\mathrm{z}$ & Sig (two) \\
\hline Effect & 0,4990 & 0,0796 & 6,2727 & 0,0000 \\
\hline
\end{tabular}

Testing the significance of indirect effects with the Sobel test obtained values of $z=6.2727$ and $p=$ 0.0000 . Because $z$-value in absolute price $>1.96$ and the level of statistical significance $\mathrm{z}$ (p-value) $<0.05$, it means that there is a mediating effect of account representative services on the relationship between tax knowledge and taxpayer compliance.

\section{DISCUSSION}

The implementation of e-Filing system

has a direct effect on account representative services

Hypothesis testing 1 proves that the application of the e-Filing system has a direct effect on the service of account representatives. The better implementation of the e-Filing system, the better the quality of account representative services felt by taxpayers. This shows that the application of e-Filing system can make taxpayers satisfied with the quality of account representative services provided because it can simplify and save time.
According to Richard Burton (in Official, 2011), an account representative is a tax officer specifically monitors the tax compliance compliance of each taxpayer he supervises (such as the Tax Payer Profile / company profile), helps speed up the process of requesting the information required by the taxpayer, monitors the completion of audits tax and the objection process and answer taxpayer questions on tax issues and inform the latest tax provisions.

This is in line with research conducted by Erawati \& Ratnasari (2018) which states that the application of e-filing has a positive effect on service quality satisfaction.

\section{Knowledge of taxation directly affects the account representative service}

Hypothesis testing 2 proves that tax knowledge has a direct effect on the service of Account Representatives. The higher the level of taxation knowledge, the better the service of Account Representatives. This is expected to occur because the information provided by the Represenative 


\section{EPRA International Journal of Research and Development (IJRD)}

Account about tax knowledge to taxpayers is already good. In addition, taxpayers know clearly about the duties of the Account Representative, so that taxpayers can make full use of the facilities of the Account Representative. So that tax knowledge affects the Account Representative service.

Account Representative at the Tax Service Office is regulated in the Decree of the Minister of Indonesia Number: 79/PMK.01/2015 explaining that Account Representative is one of the spearheads of exploring the potential of state revenue in the field of taxation which carries out the task of tax intensification through providing guidance/appeal, consultation, analysis and supervision against taxpayers (Widomoko, 2017). Another task of Account Representatives is to provide intensive supervision to taxpayers. To sustain the application of the self assessment system in Indonesia, it is very necessary the role of Account Representative (Irawan, 2013).

\section{The implementation of e-Filing system has a direct effect on the compliance of taxpayers}

Hypothesis testing 3 proves that the application of the e-Filing system has a direct effect on taxpayer compliance. This shows that the better the application of e-filing system, the Taxpayer Compliance will also be good. E-filing is part of tax administration reform that aims to facilitate taxpayers in making and submitting SPT reports to the Directorate General of Taxes. The application of the e-filing system is expected to provide comfort and satisfaction for taxpayers in fulfilling their tax obligations so that the e-filing system is expected to increase taxpayer compliance.

Rahayu (2010) states that the modernization of the taxation system within the DGT by utilizing a reliable and up-to-date information system (e-filing) is one of the strategies adopted to achieve high levels of tax compliance.

The results of this study support the findings of Tresno, et al. (2013), Suprayoga and Hasymi (2018), and Erwanda, et al. (2019), which states that the application of e-filing has a positive effect on the level of compliance of taxpayers.

\section{Knowledge of taxation directly affects the compliance of taxpayers}

Testing hypothesis 4 proves that tax knowledge directly influences taxpayer compliance. This is in accordance with the taxation system in Indonesia which adopts a self assessment system that requires taxpayers to have knowledge related to taxation regulations. Because how is it possible that taxpayers can carry out their obligations if they do not have knowledge about the rules, how to count, count to report taxes. By having adequate tax knowledge, taxpayers can know and easily carry out the obligations that must be done in terms of taxation. The higher level of knowledge possessed by taxpayers will increase taxpayer compliance because taxpayers already know the function of taxes and the importance of taxes in state development. Lack of tax knowledge possessed is the cause of the low compliance of taxpayers. Tax counseling and information dissemination can be done by tax officials to provide updated information regarding changes in tax regulations.

The results of this study support the research conducted by Viega \& Fidiana (2017); Siti, et al (2017); and Beny, et al (2018), showed that there is a positive effect of tax knowledge on taxpayer compliance.

\section{Account Representative services directly affect the compliance of taxpayers}

Hypothesis testing 5 proves that the Account Representative service has a direct effect on taxpayer compliance. This means that taxpayer compliance can be improved by the performance of an Account Representative. The services provided by the Account Representative must be excellent and in line with the expectations of the Taxpayer. Good service will provide satisfaction to taxpayers and will increase taxpayer compliance, services provided by Account Representatives will provide an encouragement to taxpayers to establish dynamic relationships with the East Tangerang Pratama Tax Office.

With the issuance of new regulations on the modernization of the taxation system, he added that the duty of tax employees as an Account Representative (AR) is one of the innovations carried out by the Directorate General of Taxes so that Taxpayers increase tax reporting. Supported by increasingly advanced taxation services, to direct taxpayers by means of counseling and make Taxpayers satisfied of the maximum service performance provided by the tax authority. Tax employees with positions as Account Representatives (AR) provide services in reporting annual tax returns in tax consultations if they experience difficulties in reporting. Account Representative services as a support for the existence of electronic system services, in addition to being a companion for taxpayers who report tax returns so that taxpayers do not feel distressed in reporting. Satisfaction felt by taxpayers in using e-Filing will form a positive attitude and further make the tax image will also get better.

\section{CONCLUSION}

Based on the analysis results, the following conclusions can be drawn: 1) The application of the e-Filing system has a direct effect on the service of Account Representatives; 2) Knowledge of taxation directly affects the service of Account Representatives; 3) The application of the e-Filing 


\section{EPRA International Journal of Research and Development (IJRD)}

system has a direct effect on the compliance of taxpayers; 4) Tax knowledge directly affects the compliance of taxpayers; and 5) Account Representative services directly affect the compliance of taxpayers.

\section{LIMITATION}

This research cannot be separated from limitations and is expected to be a source of ideas for further research. Some limitations in this study include: First, the results of this study are only based on the answers of respondents to the questionnaire distributed, and are not supported by interviews. Second, in filling out the questionnaire it is possible that the answer does not match the actual situation. This can happen when the respondent is not focused when answering the questionnaire, because there are several respondents when filling out the questionnaire while doing other activities simultaneously and some are in a hurry when filling out the questionnaire.

\section{SUGGESTIONS}

By considering the existing limitations, it is expected that future studies will improve the following factors: 1) For the East Tangerang KPP Parties, based on the results of tests conducted on each variable there are results indicated by respondents that the taxation socialization has an effect on taxpayer compliance. Actions that can be taken by the East Tangerang KPP to further improve taxpayer compliance are to expand tax socialization to taxpayers so that taxpayers are more aware of their tax rights and obligations; 2) For Further Research, based on the conclusions and limitations of the results of this study, the suggestion that can be given to future researchers is that future research can replace this research model by changing the intervening variable to another variable. This research model can also be developed by adding other variables outside this study that can affect taxpayer compliance such as tax sanction assertiveness and tax service quality. And can add other methods, such as using the interview model.

\section{REFERENCE}

1. Axel dan Mulyani. 2019. Pengaruh Tax Amnesty Terhadap Kepatuhan Wajib Pajak Dengan Pengetahuan Pepajakan sebagai Pemoderasi. Jurnal Akuntansi, Vol. 8, No. 1 Februari

2. Defantris Hari Kurniati; Mochammad Djudi M; dan Muhammad Saifi. 2016. Pengaruh Pengetahuan Perpajakan dan Kualitas Pelayanan Terhadap pelayanan Account Representative Dalam Menyampaikan Surat Pemberitahuan (SPT) Tahunan (Studi pada Wajib Pajak Orang Pribadi yang Terdaftar di KPP Pratama Blitar). Jurnal Perpajakan (JEJAK). Vol. 9, No. 1

3. Devano, Sony, dan Rahayu, Siti Kurnia. 2010. Perpajakan: Konsep, Teori, dan Isu. Jakarta:
Prenada Media Grup.

4. Diaz Priantara. 2016. Perpajakan Indonesia (Edisi 3). Jakarta: Mitrawacanamedia

5. Keputusan Direktur Jenderal Pajak Nomor KEP05/PJ/2005 tentang tata cara penyampaian Surat Pemberitahuan (SPT) secara elektronik (e-Filing) melalui perusahaan penyediaan jasa (ASP) tercantum Prosedur pelaporan SPT dengan eFiling

6. Nur Hidayati. 2010. Pengaruh Pengetahuan Pajak dan Kesadaran Wajib Pajak Terhadap Kepatuhan Pajak. Jurnal Akuntansi. Vol 4 No 1. Maret.

7. Nugroho Aditya, Rita Andini, dan Kharis Raharjo. 2016. Pengaruh Kesadaran Wajib Pajak Dan Pengetahuan Perpajakan Wajib Pajak Terhadap Kepatuhan Wajib Pajak Dalam Membayar Pajak Penghasilan (Studi Kasus Pada KPP Semarang Candi). Journal Of Accounting. Vol. 2 No. 2 Maret

8. Nurhidayah, Sari. 2015. Pengaruh Penerapan Sistem E-Filing Terhadap Kepatuhan Wajib Pajak Dengan Pemahaman Internet Sebagai Variabel Pemoderasi Pada KPP Pratama Klaten. Fakultas Ekonomi Universitas Negeri Yogyakarta. Universitas Negeri Yogyakarta.

9. Nurulita Rahayu. 2017. Pengaruh Pengetahuan Perpajakan, Ketegasan Sanksi Pajak, dan Tax Amnesty terhadap Kepatuhan Wajib Pajak. Akuntansi Dewantata. Vol. 1, No. 1.

10. Nurul Citra Noviandini. 2012. Pengaruh Persepsi Kebermanfaatan, Persepsi Kemudahan Penggunaan, dan Kepuasan Wajib Pajak Terhadap Penggunaan E-Filing Bagi Wajib Pajak di Yogyakarta. Jurnal Nominal. Volume I Nomor I

11. Pandiangan, Liberty. 2008. Reformasi Perpajakan. Jakarta: PT Salemba Empat.

12. Peraturan Direktur Jenderal Pajak Nomor PER47/PJ/2008 tentang Tata Cara penyampaian SPT secara Elektronik (e-filing)

13. Priantara, Diaz dan Supriyadi Bambang. 2011. Faktor Faktor yang Mempengaruhi Pengusaha Kecil dan Makro Mendaftar Menjadi Wajib Pajak Orang Pribadi. Jurnal Akuntansi dan Keuangan Vol 13 Nomor 2. November 2011.

14. Rahayu, Siti Kurnia. 2010. Perpajakan Indonesia: Konsep \& Aspek Formal. Yogyakarta: Graha Ilmu.

15. Ricky Alfiando Wowor, Jenny Morasa, dan Inggriani Elim. 2014. Analisis Faktor-Faktor Yang Mempengaruhi Perilaku Wajib Pajak Untuk Menggunakan E-Filling. Jurnal EMBA. Vol. 2, No. 3 September, Hal. 1340-1349

16. Rico Wijaya, Lutfi, \& Aulia Beatrice B. 2019. Influence of E-filing System Implementation against Taxpayer Compliance of the Submission the Annual Notice (SPT) by Understanding the Internet as Moderating Variable on Office Services Tax Pratama Jambi City. International Journal of Academic Research in Accounting, Finance andManagement Sciences. Vol. 9, No. 4

17. Rizki Fitri Amalia. 2016. Pengaruh Penerapan EFiling Terhadap Tingkat Kepatuhan 
Penyampaian SPT Tahunan Pajak Penghasilan Wajib Pajak Orang Pribadi Dengan Pelayanan Account Representative Sebagai Variabel Intervening di Kota Palembang. Jurnal Ilmiah Orasi Bisnis. Volume 15 Bulan Mei

18. Rusmadi. 2017. Pengaruh Tax Amnesty dan Sanksi Pajak Terhadap Kepatuhan Wajib Pajak. Syntax Literate: Jurnal Ilmiah Indonesia. Vol. 2 No. 3

19. Sidiq Prasetyo. 2017. Pengembangan EGovernment Di Dinas Pendidikan Dan Kebudayaan Kota Semarang. Journal of Public Policy and Management Review. Volume 6, Nomer 4

20. Suprayogo dan Mhd. Hasymi. 2018. Pengaruh Penerapan Sistem E-Filing Terhadap Kepatuhan Wajib Pajak Orang Pribadi Dengan Pemahaman Internet Sebagai Variabel Moderasi Pada Kantor Pelayanan Pajak Pratama Jakarta Jatinegara. Profita: Komunikasi Ilmiah Akuntansi dan Perpajakan. Vol. 11 No. 2 | Agustus

21. Tika Wulandari dan Suyanto. 2014. "Pengaruh Pengetahuan Perpajakan, Tingkat Pendidikan, dan Sanksi Administrasi Terhadap Kepatuhan Wajib Pajak Dalam Melakukan Pembayaran Pajak Bumi Bangunan". Jurnal Akuntansi. Vol.2, No.2, Desember

22. Tresno, Indra Pahala, \& Selvy Ayu Rizky. 2013. Pengaruh Persepsi Penerapan Sistem E-filing terhadap Tingkat Kepatuhan Wajib Pajak Badan dengan Perilaku Wajib Pajak sebagai Variabel Intervening dan Biaya Kepatuhan sebagai Variabel Moderasi (Studi Kasus pada Kantor Pelayanan Pajak Pratama Pulogadung Jakarta Timur). Prosiding Simposium Nasional Perpajakan 4. ppl-18.

23. Tsung Lu, Cheng, Huang, Shaio-Yan \& Pang-Yen Lo. 2010. An Empirical Study of On-line Tax Filing Acceptance Model: Integrating TAM and TPB. African Journal of Business Management, 4(5), pp: 800-810.

24. Undang-Undang Republik Indonesia Nomor 28 tahun 2007 Tentang Perubahan Ketiga Atas Undang-Undang Nomor 6 Tahun 1983 Tentang Ketentuan Umum Dan Tata Cara Perpajakan.

25. Undang Undang Nomor 11 tahun 2008 tentang Informasi dan Transaksi Elektornik

26. Waluyo. 2011. Perpajakan Indonesia, Edisi 10 buku 1. Jakarta: Salemba Empat 